\title{
Differences between studying an islet $\beta$ cell and studying whole pancreatic islets: immunological implications
}

\author{
Shoham Rigbi, Boris M Baranovski and Eli C Lewis*
}

Department of Biochemistry and Pharmacology, Faculty of Health Sciences, Ben-Gurion University of the Negev, Beer-Sheva, Israel.
"Corresponding author

Eli C Lewis, Associate Professor, Department of Clinical Biochemistry \& Pharmacology, Faculty of Health Sciences, Ben-Gurion University of the Negev 1 Rager st., Beer-Sheva 8410105, Israel, Tel/fax:+972-6400830; Email: lewis@bgu.ac.il

Submitted: 14 Feb 2017; Accepted: 06 Apr 2017; Published: 11 Apr 2017

\begin{abstract}
The main role of the pancreatic islet $\beta$ cell is to release the appropriate amount of insulin upon glucose stimulation. For this reason, islet transplantation has been advancing in the past few years as a therapeutic alternative for patients with diabetes, alongside the exciting field of manipulating $\beta$ cell differentiation for the sake of $\beta$ cell transplantation. However, do isolated $\beta$ cells function the same as $\beta$ cells within an intact islet? Within islets, $\beta$ cells are surrounded by other cell types, including endocrine cells, endothelial cells and immune cells, a proximity which appears to be relevant for proper glucose homeostasis. Although insulin and glucose are the main regulators in this scenario, other factors, such as angiogenesis, local anti-inflammatory components and the activity profile of resident macrophages, have a profound effect on the function and fate of $\beta$ cells. A paracrine interaction between $\beta$ cells and $\alpha$ cell holds a dramatic effect on $\beta$ cell function, which is additionally dependent on blood flow through the islet. Another important intercellular communication exists between $\beta$ cells and endothelial cells, in this case a bidirectional interface. Moreover, $\beta$ cell survival and proliferation is dependent on the potency of ECM proteins. Further parameters distinguish functionally between the isolated $\beta$ cell and the intact islet, including the deposition of Zinc by $\beta$ cells, synchronicity by electrical and calcium routes, the physical innervation of islets and more. In this review, we explore major parameters that relate to differences between the function of the isolated $\beta$ cell and that of the $\beta$ cell within an intact islet. These and some yet to be investigated aspects of $\beta$ cell function should be included in the list of considerations when examining therapeutic targets for $\beta$ cell-related pathologies and for the prospect of effective $\beta$ cell replacement therapy.
\end{abstract}

\section{Introduction}

Pancreatic $\beta$ cells are located within the islets of Langerhans and are responsible for the secretion of insulin upon glucose stimulation. They are surrounded by other cell types, including endocrine cells and innate immune cells, which are predominated by resident macrophages [1]. In addition to their low proliferative capacity, $\beta$ cells are critically damaged and eventually expire by either autoimmune responses, in the case of type 1 diabetes, or by the overwhelming requirement for insulin secretion in the case of type 2 diabetes [2]. In addition, several relatively common drugs were reported to impair $\beta$ cell function $[3,4]$. In the past several years, $\beta$ cell replacement therapy has gained attention as a possibility for addressing $\beta$ cell loss; unlike whole pancreas transplantation, it has become feasible to explore both pancreatic islet transplantation of islets isolated from organ donors, and cell grafting of singular $\beta$ cells from sources such as stem cells, transformed cells or human $\beta$ cell lines [5-7].

With the advent of addressing both whole islets and $\beta$ cells as legitimate transplantation candidates, a wide range of less-studied aspects of $\beta$ cell physiology become highly relevant, particularly when considering the expectation for a relatively physiological $\beta$ cell function following engraftment. Although $\beta$ cells are indeed the primary producers of insulin and thus play an obvious and significant role in glucose homeostasis in both health and disease, there is evidence to suggest that the $\beta$ cell is not an independent entity; it functions under the influence of its neighboring cells within the whole islet. Therefore, the utilization of $\beta$ cells for clinical purposes should take into consideration differences between the behavior of isolated $\beta$ cells, and their behavior in their native environment of clustered cells, namely, the pancreatic islet.

In the present review, we explore several major parameters that may lack in a $\beta$ cell outside the whole islet, potentially affecting the desired clinical outcome of $\beta$ cell replacement therapy. Considering some advantages of the approach which employs singular $\beta$ cell grafting, the insights that we hereby surface may allow one to consider the elaboration of some creative steps for achieving optimal glucose homeostasis in the grafted diabetic patient.

Islet structure as a parameter in $\beta$ cell function

The primary focus of $\beta$ cell research in the past few decades has been insulin secretion, and more recently with regards to differentiation 
and replication. Discoveries in the field of insulin and insulin secretion have led to important insights and to the development of highly useful drugs, but the cure for both autoimmune and auto inflammatory diabetes is still far from satisfactory; other factors, such as angiogenesis, local anti-inflammatory components and the activity profile of the immune system, have a profound effect on the function and fate of $\beta$ cells within the islet.

About 1 million islets are present in the pancreas from the time of birth, constituting $1-2 \%$ of total pancreatic mass. They contain $65-90 \%$ insulin-releasing $\beta$ cells, $15-20 \%$ glucagon-releasing $\alpha$ cells, $3-10 \%$ somatostatin-producing $\delta$ cells and $1 \%$ pancreatic polypeptide-producing (PP) cells. They also contain $3 \%$ of a variety of resident leukocytes [8]. In addition, the complete islet incorporates endothelial cells and fibroblasts, which are known to respond to inflammatory signals. While cell composition may clearly represent a component of an islet's function, it is also evident that the structure of the islet may play a role in its functionality [9]. Importantly, islet structure is species specific [10], rendering outcomes that were derived from studies of various species not necessarily translatable to human islets.

Animal models in diabetes: $\boldsymbol{\beta}$ cells or whole islets?

Animal models are readily used for the study of diabetes. There are different models for hyperglycemia that attempt to represent either insulin resistance or an immune system-mediated demise of islets. For example, the Zucker diabetic fatty (ZDF) rat serves as a model for insulin resistance and obesity. In contrast, there are models for insulin resistance that are not related to obesity, such as the GotoKakizaki (GK) Rat. Each model has its strengths and weaknesses, and none of the presently practiced models completely overlaps diabetes in humans [11]. Representing autoimmune diabetes, the non-obese diabetic (NOD) mouse is largely the only animal model in which the immune system spontaneously attacks the $\beta$ cells of the animal; syngeneic, allogeneic and xenogeneic immune responses to islets are examined by studying islet transplantation. As in the case of models for representing type 2 diabetes, none of the $\beta$ cell immune-destructive models overlap the human condition to the fullest. Yet, without exception, these models do provide a fantastic platform for the study of the whole islet, at times within an intact pancreas, in the context of a full-blown immune presence and systemic metabolic shifts, both feats that are relatively inaccessible in humans in a non-invasive manner.

$\beta$ cells are highly reactive to local conditions of stress, as depicted both in vitro and in vivo [12]; in the whole islet, their reactivity may be further modified by the presence of reactive resident immune cells. Surprisingly, $\beta$ cell reactivity to stress is evident even in temporary benign conditions. For example, under physiological conditions, inflammatory signals and nitric oxide (NO) cause temporary $\beta$ cell silencing that is further enhanced by peripheral insulin resistance, in effect causing circulating glucose levels to rise in a transitory manner [13]. Indeed, present within each islet, macrophages appear to be vital to pancreatic survival in normal state, but, as can be expected from such a responsive innate immune cell, we risk their turning harmful under excessive stress. Releasing IL-1 $\beta$ upon almost any perceived threat, macrophages will cause local $\beta$ cells to enter a mode of ER stress [14].

At the molecular level, various features have a profound effect on $\beta$ cell physiology. One of the central components of functionality involves cAMP, a second messenger which mediates multiple biological processes. Several studies have found that the amplitude of glucose-induced insulin secretion is affected by cAMP levels $[15,16]$, which indicates that it holds a significant role in insulin secretion regulation; cAMP is also affected by inflammatory signals $[17,18]$, thus potentially compromising $\beta$ cell function upon dysregulation. Another molecular aspect in $\beta$ cell function during stress involves short non-coding RNA sequences (miRNA), thought to have a significant role in the regulation of cellular functions [19]. Alterations in miRNAs has been implicated in the pathogenesis of a few diseases, including pancreatic pathologies [20]. The relevance of miRNAs to both $\beta$ cell function under steady-state conditions and during stressful conditions, renders them an important partner in the fate of $\beta$ cells in disease. The delicate regulation of both cAMP and miRNAs in $\beta$ cell physiology represents a small sample out of a myriad of intersections between the profile of the isolated $\beta$ cell, and its profile as an intimate part of the islet, whereas various signaling events spur in response to unique external triggers, and, as we elaborate in the present review, alter the behavior of cells surrounding the $\beta$ cell.

$\beta$ cells interact with neighbor cells within the islet in a paracrine manner [21]. $\alpha$ cells hold a dramatic effect on $\beta$ cell function and are only represented in experimental systems that are comprised of whole islets or, at the least, mixed cultures of $\alpha$ and $\beta$ cells. In vitro experiments had established that isolation of $\alpha$ cells from $\beta$ cells may explain the low secretory activity of isolated $\beta$ cells in comparison to whole islets [22]. Other peptides, primarily related to glucagon, such as glucagon-like peptide 1 (GLP-1) and glucosedependent insulinotropic polypeptide (GIP) may contribute to $\alpha$ cell-dependent insulin regulation [23].

Taken together, the study of the pure $\beta$ cell is indeed challenging. The methods we use in research may not provide a reliable image of the behavior of the native $\beta$ cell within an islet. In this review, we will present several issues relating to differences between the isolated $\beta$ cell, and the $\beta$ cell within an islet, and try to communicate some major considerations to be raised when examining therapeutic targets for $\beta$ cell-related pathologies.

\section{$\beta$ cells are exceptionally devoted to insulin secretion}

Of the cell types that produce large amounts of a single protein, islet $\beta$ cells appear to sacrifice quite a bit so as to execute this critical feat. They readily permit a sharp entry of high concentrations of glucose, upon which they will surpass classic carbohydrate metabolic regulation to generate a spike in ATP, which will drastically alter the function of membrane channels [24]. Even neuronal cells, which endure dramatic and rapid fluctuations in their cell membrane properties and invest major resources in granule exocytosis, are exempt from spikes in ATP and are also not devoted to a single protein transcript. For this to occur in $\beta$ cells, the cells drive the mitochondrial electron transport chain to its limit, risking the emergence of free radicals upon each glucose spike [25]. At the same time, they contain perhaps the lowest concentrations of restorative reducing agents, such as glutathione, compared to other cell types [26]. In addition, the cells run a protein production factory that is at the verge of ER stress due to unfolded protein response upon excessive demand for insulin [27]. The $\beta$ cells are thus relatively inflexible under conditions that require change in these pathways, and shutdown production by default upon any sign of cellular stress, protecting themselves from a cellular crisis. It is 
possible that for this reason, islet adaptation relies on islet mass expansion [28] and not on stretching the activity profile of each $\beta$ cell. Therefore, one may speculate that the presence of non- $\beta$ cells within islets is essential for allowing $\beta$ cells to remain viable under changes in local stress levels.

Disparity between $\beta$ cells within an islet and isolated $\beta$ cells has been described in regards to the secretory insulin response to glucose; this quintessential secretory response is compromised in isolated $\beta$ cells [29]. Few hypotheses were suggested for this phenomenon, including glucagon secretion by $\alpha$ cell [29], involvement of receptors on $\beta$ cells and the microstructure of the islet [30,31]. In support of the requirement for an intact islet as key to achieving optimal $\beta$ cell responses, miRNA and protein content appear to be shared between $\beta$ cells and non- $\beta$ cells: $85 \%$ of insulin-regulating miRNA molecules are common in both islets and isolated $\beta$ cells and differences between islets and isolated $\beta$ cells were observed at the levels of expression of proteins that participate in granule secretion, differentiation, maturation and structural arrangement $[32,33]$. These sporadic pieces of evidence are still under investigation, yet they already provide important benchmarks for the notion that an isolated $\beta$ cell is deficient in insulin regulation by virtue of a lack in supporting neighboring cells.

Islet structure: 'it takes a village' to support the $\beta$ cell $\beta$ cells are surrounded by cells that are suggested to have a significant effect on $\beta$ cell function. Whether in rodents or human islets, $\beta$ cells are positioned in proximity to $\alpha$ and $\delta$ cells, among others; presumably, these cells all behave differently upon isolation. In rodents, the ratio between $\alpha$ cells and $\beta$ cells is higher than in humans, and the spatial organization is of a mantle containing non- $\beta$ cells with a core containing exclusively $\beta$ cells; the $\alpha$ cells appear to 'crown' a sphere of $\beta$ cells [10]. In humans, islet cells form trilaminar plates comprised of 2 layers of $\alpha$ cells that surround a layer of $\beta$ cells; the two cell types appear macroscopically to be almost randomly distributed within the islet [34]. This disparity between human and rodent islets is especially interesting when observing isolated $\beta$ cell characteristics, as the differences between isolated $\beta$ cells from different species may lay in differences in their original islet structure. Interestingly, regardless of the anatomical arrangement within islets, added glucagon will increase glucoseinduced insulin secretion in isolated $\beta$ cell preparations, and oversecretion of insulin will prevent paracrine glucagon secretion by $\alpha$ cells [35]. Concomitantly, $\delta$ cells will inhibit both glucagon and insulin secretion at normal glucose levels.

\section{Zinc released from, and to, $\beta$ cells}

Although it seems that insulin and glucose are key regulators in this scenario, other factors are inherently involved in regulation of $\beta$ cell function. Zinc, which is released along with insulin during exocytosis, might be a modulator of insulin regulation, as demonstrated in rat models [36]. Indeed, a significant concentration of zinc is deposited in the interstitial space between islet cells immediately after insulin is secreted [37]. Zinc is a crucial element in the proper function of $\beta$ cells. For example, Zinc is essential for creating the hexameric structure of insulin, which is an important part of insulin processing and storage. Zinc also plays a significant role in $\beta$ cell homeostasis and has a profound effect when cosecreted with insulin. For example, some studies suggest that Zinc may influence insulin secretion through a negative feedback response, possibly explaining the deficient glucose-dependent insulin release from isolated $\beta$ cells. Zinc relates to cytokineinduced damage by oxidative stress (in part as it serves a critical role in the electron transport chain), and is thus crucial for proper evaluation of $\beta$ cells, whether isolated or within intact islets, as well as between islets of different species. For example, there are fundamental differences in protein identity between the zinc transporter ZnT8 in mice and rats, in comparison to humans [38]. Moreover, the possibility that $\beta$ cell-deposited zinc might affect $\alpha$ cells is still unclear, which is to say that some parameters of $\beta$ cell physiology might be lacking in systems that examine isolated $\beta$ cells [39].

Intercellular communications are abundant in the pancreatic islet

Mathematical models regarding cell communication in islets predict few advantages to this intercellular behavior, such as the dynamic stability between $\alpha$ and $\beta$ cells under varying glucose levels. According to one model, cells of each type can be either in an active or silent state at any given moment [35]. It is claimed that these interactions are beneficial in blood glucose regulation. Nonetheless, some of the relationships between cells appear somewhat paradoxical, such as glucagon increment of insulin secretion. More perplexingly, hormone release mechanism is common both to $\alpha$ and $\beta$ cells (i.e., ATP super-spike followed by potassium channel alterations) [40]. It is not clear why $\alpha$ cells react in the opposite manner in response to a rise in glucose; some suggest membrane potential differences, or voltage gated calcium channel differences in $\alpha$ cells. Indeed, $\beta$ cell electrical coupling increases insulin secretion, similar to the tight coupling between electrical activity and exocytosis in $\alpha$ cells. It has even been suggested that $\alpha$ cells might have a role in insulin secretion through electrical coupling with $\beta$ cells [41]. The differences in outcomes between $\beta$ cell coupling in isolated $\beta$ cells and islets is presently not fully understood.

Blood-flow through the islet appears to surpass interspecies structural differences, holding implications on the paracrine relationship between $\alpha$ and $\beta$ cells. A few models have been suggested, the dominant one stating that blood flow in islets always starts from the $\beta$ cells and then reaches non- $\beta$ cells, e.g., $\alpha$ cells [42]. Indeed, in isolated rat pancreatic cells, local release of glucagon has no effect on glucose-induced insulin secretion [43]. This phenomenon may indicate that glucagon does not necessarily contact glucagon/GLP-1 receptors on $\beta$ cells, but rather its distant tissue targets, i.e., liver and fat.

\section{Blood vessels, islets and diabetes}

Damage to blood vessels (angiopathy) is a chronic complication of diabetes, expressed both as microangiopathy and macroangiopathy, and is one of the primary causes of diabetes-related morbidity worldwide [44]. Common clinical presentations of angiopathy include retinopathy, peripheral vascular disease and nephropathy, and can result in blindness, limb amputation and kidney failure.

Animal models for diabetes present with dramatic changes regarding blood vessels function and response: islet capillary density is twice higher in young ZDF rats and GK rats display abnormal insulin release associated with blood vessels and oxidative stress [45,46]. These impaired release events are suspected to be the result of inflamed endothelial cells (EC), which 
may evoke an inflammatory response in resident immune cells and also attract circulating monocytes into the affected islets. It is thus evident that $\beta$ cells alone cannot explain the outcomes and complications of diabetes, supporting the notion that blood vessel well-being holds a significant role in this important pathology.

\section{The $\beta$ cell-capillary interface}

Pancreatic islets are a highly vascularized micro-organ, abundant in loci of direct contact between $\beta$ cells and endothelial cells. The importance of the relationship between $\beta$ cells and endothelial cells has been recognized in the past few years regarding islet transplantation and diabetes prevention, primarily because microvascular intra-islet changes have been shown to precede hyperglycemia [45]. One drawback of such studies may be the weighted focus on isolated islets rather than the whole pancreatic vasculature. This is understandable considering islet transplantation is a clinically viable entity, yet it grows distant from physiological islet regulation within the complete pancreas. For instance, smaller islets are supplied with nutrients by diffusion and larger islets are irrigated by independent blood vessels [47]. Indeed, the relationship between these two cell types, endothelial cells and $\beta$ cells, is well documented and is hereby discussed.

\section{Effect of endothelial cells on $\beta$ cells}

$\beta$ cells are influenced by important factors that are expressed by endothelial cells, including angiogenic factors and growth factors. Thrombospondin-1 (TSP-1) is expressed almost exclusively by intra-islet EC and functions as an anti-angiogenic factor [48]. TSP1 interacts with growth factors, cytokines and ECM components, causing cells within the islet to secrete TGF $\beta$ and to activate latent TGF $\beta$ [49]. This is an important regulatory process of cell growth and differentiation, as well as immune modulation through cytokines and insulin gene expression. For example, it has been shown that in the presence of high glucose, TSP-1 levels are significantly increased, and subsequently an increase in TGF $\beta$ levels is observed [50]. These observations might suggest that high levels of glucose would benefit $\beta$ cell function, however, TSP $-1^{-/}$mouse islets display a larger $\beta$ cell mass and superior vascularization, alongside, quite paradoxically, glucose intolerance $[51,52]$.

Endothelial cells express hepatocyte growth factor (HGF), a proangiogenic factor which was found to bind to c-Met receptors on $\beta$ cells [53]. This interaction activates RAS and PI3K signaling cascades that relate to cell proliferation and survival. HGF transgenic mice exhibit over expression of HGF in $\beta$ cells, and display 2-fold greater insulin levels, and 2-3-fold greater $\beta$ cell mass [54]. In contrast, mice that lack components of HGF signaling pathway exhibit normal glucose homeostasis and normal $\beta$ cell mass [55]; interestingly, they are nonetheless more vulnerable to NF- $\mathrm{BB}$-mediated cytokine damage [55]. Indeed, HGF might have a key role in islet transplantation prognosis due to its role in cytokine-induced cell injury. Another aspect of HGF expression involves its relation to VEGF-A, as in the liver, suggesting a role in the dynamic of the vascular bed maintenance in islets [46].

One of the fundamental interactions of tremendous importance for $\beta$ cell function is between $\beta$ cells and non-cellular entities. ECM proteins include nidogens (formerly known as entactins), collagen type IV, perlecan, laminin, heparan sulfate, fibronectin and more. This basement membrane creates a physical barrier between the immune system and $\beta$ cells during the development of diabetes; most importantly, $\beta$ cells are dependent on endothelial cells to synthetize the basement membrane. ECM components increase $\beta$ cell survival and proliferation within islets, and increase insulin expression through $\beta 1$-integrin connectivity to the $\beta$ cell surface $[56,57]$. The link between laminin 411 and 511 , and $\beta 1$-integrin, is extremely potent in regards to $\beta$ cell proliferation and insulin production [58]. In addition, EC secrete collagen type IV, which binds to $\alpha 1 \beta 1$-integrin and increases insulin secretion [46]. In ZDF rats, thickening of ECM and loss of fenestrations causes an increase in VEGF-A expression by $\beta$ cells [59]. As a result, ECM is overproduced and partakes in the recruitment of immunocytes via inflammatory signals, causing irreversible damage to islets.

In addition to the ECM itself, proteins related to ECM have a significant effect on $\beta$ cells. Connective tissue growth factor (CTGF), a matricellular protein of ECM-associated heparin binding proteins, affects $\beta$ cell proliferation, differentiation and islet morphogenesis [60]. CTGF is expressed during embryonic development, and loss of the protein will cause a decrease in $\beta$ cell mass and islet vasculature [61]. CTGF induces PDGF-B overexpression in EC, which is required for pericyte recruitment [50]. Pericytes have a major impact on vasodilation, and thus might contribute to insulin resistance. Interestingly, Cao et al. report that $\alpha$ cell mass is increased in $\mathrm{CTGF}^{-/-}$mice [50]. Therefore, CTGF might play a role in $\beta$ cell differentiation and in $\alpha$ cell proliferation, though a receptor for CTGF in $\beta$ cells has yet to be identified.

Transmembrane proteins are also an important factor in the unique interactions between EC and $\beta$ cells. Increased insulin content and islet size enlargement can be caused by connexin $\mathrm{Cx} 43$ overexpression, which, during steady-state, is highly expressed by $\mathrm{EC}$ in comparison to $\beta$ cells [48]. Other connexins might affect this intercellular interaction, especially when considering the proximity between the two cell types, $\beta$ cells and ECs.

\section{Effect of $\beta$ cells on $\mathrm{EC}$}

Perhaps the most important factor that relates to $\mathrm{EC}$ and is expressed by $\beta$ cells is VEGF-A. VEGF-A is regulated by the $\beta$-cell-specific $\mathrm{Pdx} 1$ promoter, and $\beta$ cells secrete large amounts of the mediator during early and adult life [62]. VEGF-A acts on VEGFR-2 receptor, which is primarily expressed on intra-islet capillaries and is downregulated in pancreatic exocrine cells [62]. Its function includes migration and proliferation of EC, as well as preservation of intact capillary fenestrations. It is regulated in $\beta$ cells by hypoxia and glucose levels, and to the presence of other angiogenesis or anti-angiogenesis factors. Mice that lack VEGF-A still have blood vessels, suggesting that some redundant factors play a role in intra-islet capillary maintenance; nonetheless, blocking VEGF-A results in a significant decrease in capillary density [48]. Exedin-4, a glucagon-like protein-1 (GLP-1) receptor agonist, restores VEGF-A levels and promotes blood vessels density [48].

VEGF-A production by $\beta$ cells is down regulated during hyperglycemic conditions, most probably due to islet inflammation [50]; such VEGF-A inactivation results in the development of glucose intolerance, and suggests that this factor might have a role in the early stages of diabetes. Moreover, in this regard, insulin secretion may be a synergistic process alongside VEGF-A release, causing EC to secrete $\mathrm{HGF}$ and by this facilitating $\beta$ cell proliferation and adaptive islet expansion. 
Contributing to electrical coupling between adjacent $\beta$ cells, Connexin36 (Cx36) serves as a prominent gap junction protein inherently involved in glucose-induced calcium oscillations [63]. Islets that lack $\mathrm{Cx} 36$ present with increased basal insulin secretion, alongside compromised glucose-induced insulin secretion [64]. The gene for $\mathrm{Cx} 36$ resides in a locus that is associated with heightened risk for diabetes type 2 [65], supporting the notion that a dysfunctional Cx36 may be involved in the pathogenesis of diabetes.

Endothelial cells respond to local $\beta$ cell-derived insulin by increasing the expression of NO sythetase [66]. In fact, excessive NO might take part in promoting $\beta$ cell apoptosis in diabetes [67]. EC and $\beta$ cells are affected dramatically by stress-induced situations. Islet transplantation is one example of this scenario. The preparation process of isolated islets for the purpose transplantation holds many stressful points which might influence transplantation prognosis; islets from the donor are severed from their rich blood supply in the pancreas, resulting in a lack of basic infrastructure for rapid revascularization upon engraftment. Indeed, at least $60 \%$ of the $\beta$ cell mass is readily lost after their transplantation, mostly attributed to the isolation process.

Transplantation of $\beta$ cells versus whole islets: the aspect of inflammation and immunity

The concept of surgical replacement of the lacking $\beta$ cells in patients with diabetes has come a long way since the first $\beta$ cell and islet transplantation procedures had begun. Transplantation of differentiated $\beta$ cells and even of stem cells that will differentiate into $\beta$ cell, is an example of attempts to overcome limitations involved in isolating islets from human donors. A variety of methods have been developed to enhance $\beta$ cell survival, and one of the most profound improvements was achieved by co-transplantation of both $\beta$ cells and EC [68]. Similarly, over expression of VEGF-A in transplanted islets increased $\beta$ cells survival [69]. Alternative sources for islets, i.e., xenotransplantation, is also an important avenue in $\beta$ cell replacement therapy, yet it faces constraints that overlap some of the major limitations in human islet isolation, including the withstanding of oxidative damage and local inflammatory cytokines $[70,71]$.

The immune system is involved in several pancreatic pathologies. Factors that gravely affect $\beta$ cell survival include IL- $1 \beta$, IFN $\gamma$ and TNF $\alpha$; although an essential molecule, high levels of NO synthetized by cytokine-elicited iNOS will cause a toxic decrease in $\beta$ cell ATP production [67]. Importantly, the effect of NO on $\beta$ cells displays some species-specific differences: unlike in rodent studies, iNOS inhibitors attenuate cytokine-mediated human islet injury by only about $50 \%$, suggesting that human islets are less sensitive to NO in comparison to rodents [72].

The way $\beta$ cells react to inflammation changes dramatically between isolated $\beta$ cells and whole islet $\beta$ cells. For example, the human pancreatic $\beta$ cell line EndoC- $\beta \mathrm{H} 1$ does not respond to cytokines in the same way that human islets do; it fails to produce $\mathrm{NO}$ in response to inflammatory cytokines, and inhibitors of NO do not prevent cell injury within the cell line [72]. Insulin secretion in normal cytokine-treated $\beta$ cells is impaired by NO-dependent inhibition of the process of oxidative phosphorylation. Yet EndoC$\beta \mathrm{H} 1$ cells display injury irrespective of oxidative phosphorylation. Some reports depict a key role for NO in generating ER stress in rat islets, but not in mouse or human islets [14].

Another important factor that arises during inflammation in islets is heat shock protein 70 (HSP70), a protein that protects cells from stress-induced injury and, for this matter, nitric oxide toxicity in human islets $[73,74]$. Islets and $\beta$ cell lines that overexpress HSP70 are resistant to cytokine injury, but unlike in the case of whole islets, cell lines that overexpress HSP70 are also resistant to ER stress activators [75].

Islet resident macrophages

While it is clear that $\beta$ cells are highly responsive to their immediate cytokine environment, they reside in close proximity to local macrophages. M1 and M2 depict classic and alternative activation profiles of macrophages [76], each associated with reciprocally different factors: M1 is associated with IFN $\gamma$ and M2 with IL-4. The former relates to the acute inflammatory response, and the latter with tissue maintenance and repair. Resident macrophages are found in the inter-acinar stroma and in islets, although they differ in their characteristics. In islets, resident macrophages represent the only myeloid cell population, their population size is dependent on macrophage colony stimulating factor 1 (CSF-1) [8]. These express IL- $1 \beta$ and TNF $\alpha$ under steady state conditions and high levels of MHC class II; i.e., they are of the M1 pole [8]. They have been suggested as effector cells in $\beta$ cell destruction during the development of autoimmune diabetes [77]. For instance, $\mathrm{TNF} \alpha$, IFN $\gamma$ and IL-1 $\beta$ induce iNOS expression in resident macrophages and consequently, local NO levels reach $\beta$ cell-toxic concentrations. While this is obviously an unwanted reaction, the study of isolated $\beta$ cells that lack this intimate response might not reflect an authentic progression of diabetes.

The important component of direct islet innervation

Both $\beta$ and $\alpha$ cells respond to signals from the nervous system [78]. $\alpha$ cells are stimulated by the sympathetic division, which simultaneously inhibits $\beta$ cell secretion of insulin and facilitates a sharp rise in blood glucose levels. Electrophysiological studies have established significant differences between the electrical properties of the two cell types, and between isolated $\beta$ cells and $\beta$ cells within intact islets [40]. For example, $\beta$ cells within intact islets will respond to extracellular glucagon with two spikes: an initial responsive spike followed by a burst of a reaction; isolated $\beta$ cell only display the latter spike. The pulsatile nature of insulin release is a result of simultaneous firing and calcium load in $\beta$ cell syncytium. $\beta$ cells within islets respond to stimulatory glucose concentrations with synchronous and homogeneous calcium currents, that are absent in isolated $\beta$ cells (i.e., isolated $\beta$ cells display asynchronous calcium currents). This oscillatory pattern has important advantages, including the reset of secretory and peripheral effector mechanisms, and is important for the finetuning of $\beta$ cell responses. The coupling of $\beta$ cell responses between each other and their modification by the presence of $\alpha$ cell-derived glucagon, might be responsible for a significant part of the observed differences between $\beta$ cell behavior in their isolated form and $\beta$ cells in their physiological positioning within intact islets.

One of the factors that might affect the outcome of islet transplantation is islet innervation. The pancreatic islet is innervated as part of the digestive system, but once the islets or cells are dislodged, it is unclear how host-derived axons find their 
way in order to regulate secretion in a transplanted patient or animal. Indeed, the separation of the islets or isolated cells might damage their ability for re-innervation or any other electrical activity between the cells, or between islets and the entire secretory system. This might be another key cause for the limited outcomes in islet transplantation that deserves further research.

\section{Conclusion}

While important advances have been gained in our understanding of $\beta$ cell differentiation and the factors required for this complex process, it appears that the isolated $\beta$ cell is somewhat removed from its optimum capacity to regulate blood glucose levels. Nonetheless, by exploring the requirements of the $\beta$ cell in as far as neighbor cells and dynamic local factors are concerned, one may anticipate the emergence of $\beta$ cell replacement outside the realm of islet grafting. Together with major advances in genetic engineering in general and in that respect, of islet cells, it may be feasible to replace whole islet grafts with more durable and potent $\beta$ cell transplants. That said, the multitude of factors that affect the function of a $\beta$ cell are still not fully understood, and require extensive research; to that end, the prominent distinctions that have been described to exist between the whole islet and the isolated $\beta$ cell must be taken into consideration.

\section{References}

1. Morris DL (2015) Minireview: Emerging Concepts in Islet Macrophage Biology in Type 2 Diabetes. Mol Endocrinol 29: 946-962.

2. Butler AE, Janson J, Bonner-Weir S, Ritzel R, Rizza RA, et al.(2003) Beta-cell deficit and increased beta-cell apoptosis in humans with type 2 diabetes. Diabetes 52: 102-110.

3. Mazzola N (2012) Review of current and emerging therapies in type 2 diabetes mellitus. Am J Manag Care 18: S17-26.

4. Izzedine H, Launay-Vacher V, Deybach C, Bourry E, Barrou B, et al. (2005) Drug-induced diabetes mellitus. Expert Opin Drug Saf 4: 1097-1109.

5. Dominguez-Bendala J, Ricordi C (2012) Present and future cell therapies for pancreatic beta cell replenishment. World J Gastroenterol 18: 6876-6884.

6. Okere B, Lucaccioni L, Dominici M, Iughetti L (2016) Cell therapies for pancreatic beta-cell replenishment. Ital J Pediatr 42: 62 .

7. Newby BN, Terada N, Mathews CE (2014) In search of a surrogate: engineering human beta cell lines for therapy. Trends Endocrinol Metab 25: 378-380.

8. Calderon B, Carrero JA, Ferris ST, Sojka DK, Moore L, et al. (2015) The pancreas anatomy conditions the origin and properties of resident macrophages. The Journal of experimental medicine 212: 1497-1512.

9. Cabrera O, Berman DM, Kenyon NS, Ricordi C, Berggren PO, et al. (2006) The unique cytoarchitecture of human pancreatic islets has implications for islet cell function. Proceedings of the National Academy of Sciences of the United States of America 103: 2334-2339.

10. Steiner DJ, Kim A, Miller K, Hara M (2010) Pancreatic islet plasticity: interspecies comparison of islet architecture and composition. Islets 2: 135-145.

11. Calcutt NA, Cooper ME, Kern TS, Schmidt AM (2009) Therapies for hyperglycaemia-induced diabetic complications: from animal models to clinical trials. Nat Rev Drug Discov 8: 417-429.
12. Robertson RP (2009) Beta-cell deterioration during diabetes: what's in the gun? Trends Endocrinol Metab 20: 388-393.

13. Sharma PR, Mackey AJ, Dejene EA, Ramadan JW, Langefeld CD, et al. (2015) An Islet-Targeted Genome-Wide Association Scan Identifies Novel Genes Implicated in Cytokine-Mediated Islet Stress in Type 2 Diabetes. Endocrinology 156: $3147-$ 3156.

14. Brozzi F, Nardelli TR, Lopes M, Millard I, Barthson J, et al. (2015) Cytokines induce endoplasmic reticulum stress in human, rat and mouse beta cells via different mechanisms. Diabetologia 58: 2307-2316.

15. Dyachok O, Idevall-Hagren O, Sagetorp J, Tian G, Wuttke A, et al. (2008) Glucose-induced cyclic AMP oscillations regulate pulsatile insulin secretion. Cell Metab 8: 26-37.

16. Tengholm A (2012) Cyclic AMP dynamics in the pancreatic beta-cell. Ups J Med Sci 117: 355-369.

17. Moore AR, Willoughby DA (1995) The role of cAMP regulation in controlling inflammation. Clinical and experimental immunology 101: 387-389.

18. Serezani $\mathrm{CH}$, Ballinger MN, Aronoff DM, Peters-Golden M (2008) Cyclic AMP: master regulator of innate immune cell function. Am J Respir Cell Mol Biol 39: 127-132.

19. Osmai M, Osmai Y, Bang-Berthelsen CH, Pallesen EM, Vestergaard AL, et al. (2016) MicroRNAs as regulators of beta-cell function and dysfunction. Diabetes Metab Res Rev 32: 334-349.

20. Yu J, Li A, Hong SM, Hruban RH, Goggins M (2012) MicroRNA alterations of pancreatic intraepithelial neoplasias. Clin Cancer Res 18: 981-992.

21. Caicedo A (2013) Paracrine and autocrine interactions in the human islet: more than meets the eye. Semin Cell Dev Biol 24: 11-21.

22. Pipeleers DG, Schuit FC, Van Schravendijk CF, Van de Winkel M (1985) Interplay of nutrients and hormones in the regulation of glucagon release. Endocrinology 117: 817-823.

23. Moens K, Heimberg H, Flamez D, Huypens P, Quartier E, et al. (1996) Expression and functional activity of glucagon, glucagon-like peptide I, and glucose-dependent insulinotropic peptide receptors in rat pancreatic islet cells. Diabetes 45: 257-261.

24. Keizer J, Magnus G (1989) ATP-sensitive potassium channel and bursting in the pancreatic beta cell. A theoretical study. Biophys J 56: 229-242.

25. Tanaka Y, Tran PO, Harmon J, Robertson RP (2002) A role for glutathione peroxidase in protecting pancreatic beta cells against oxidative stress in a model of glucose toxicity. Proceedings of the National Academy of Sciences of the United States of America 99: 12363-12368.

26. Grankvist K, Marklund SL, Taljedal IB (1981) CuZnsuperoxide dismutase, Mn-superoxide dismutase, catalase and glutathione peroxidase in pancreatic islets and other tissues in the mouse. Biochem J 199: 393-398.

27. Fonseca SG, Burcin M, Gromada J, Urano F (2009) Endoplasmic reticulum stress in beta-cells and development of diabetes. Curr Opin Pharmacol 9: 763-770.

28. Szabat M, Page MM, Panzhinskiy E, Skovso S, Mojibian M, et al. (2016) Reduced Insulin Production Relieves Endoplasmic Reticulum Stress and Induces beta Cell Proliferation. Cell Metab 23: 179-193.

29. Pipeleers DG, Schuit FC, in't Veld PA, Maes E, HooghePeters EL, et al. (1985) Interplay of nutrients and hormones in 
the regulation of insulin release. Endocrinology 117: 824-833.

30. Schuit FC, Pipeleers DG (1986) Differences in adrenergic recognition by pancreatic A and B cells. Science 232: 875877.

31. Iwashita N, Uchida T, Choi JB, Azuma K, Ogihara T, et al. (2007) Impaired insulin secretion in vivo but enhanced insulin secretion from isolated islets in pancreatic beta cellspecific vascular endothelial growth factor-A knock-out mice. Diabetologia 50: 380-389.

32. van de Bunt M, Gaulton KJ, Parts L, Moran I, Johnson PR, et al. (2013) The miRNA profile of human pancreatic islets and beta-cells and relationship to type 2 diabetes pathogenesis. PLoS One 8: e55272.

33. Terra LF, Teixeira PC, Wailemann RA, Zelanis A, Palmisano G, et al. (2013) Proteins differentially expressed in human beta-cells-enriched pancreatic islet cultures and human insulinomas. Mol Cell Endocrinol 381: 16-25.

34. Bosco D, Armanet M, Morel P, Niclauss N, Sgroi A, et al. (2010) Unique arrangement of alpha- and beta-cells in human islets of Langerhans. Diabetes 59:1202-1210.

35. Jo J, Choi MY, Koh DS (2009) Beneficial effects of intercellular interactions between pancreatic islet cells in blood glucose regulation. J Theor Biol 257: 312-319.

36. Faure P, Roussel AM, Martinie M, Osman M, Favier A, et al. (1991) Insulin sensitivity in zinc-depleted rats: assessment with the euglycaemic hyperinsulinic clamp technique. Diabete Metab 17: 325-331.

37. Gyulkhandanyan AV, Lu H, Lee SC, Bhattacharjee A, Wijesekara N, et al. (2008) Investigation of transport mechanisms and regulation of intracellular $\mathrm{Zn} 2+$ in pancreatic alpha-cells. The Journal of biological chemistry 283: 1018410197.

38. Li YV (2014) Zinc and insulin in pancreatic beta-cells. Endocrine 45: 178-189.

39. Ravier MA, Rutter GA (2005) Glucose or insulin, but not zinc ions, inhibit glucagon secretion from mouse pancreatic alphacells. Diabetes 54: 1789-1797.

40. Kitasato H, Kai R, Ding WG, Omatsu-Kanbe M (1996) The intrinsic rhythmicity of spike-burst generation in pancreatic beta-cells and intercellular interaction within an islet. Jpn J Physiol 46: 363-373.

41. Barg S, Galvanovskis J, Gopel SO, Rorsman P, Eliasson L (2000) Tight coupling between electrical activity and exocytosis in mouse glucagon-secreting alpha-cells. Diabetes 49: $1500-1510$

42. Nyman LR, Wells KS, Head WS, McCaughey M, Ford E, et al. Real-time, multidimensional in vivo imaging used to investigate blood flow in mouse pancreatic islets. J Clin Invest 118: 3790-3797.

43. Moens K, Berger V, Ahn JM, Van Schravendijk C, Hruby VJ, et al. (2002) Assessment of the role of interstitial glucagon in the acute glucose secretory responsiveness of in situ pancreatic beta-cells. Diabetes 51: 669-675.

44. Cade WT (2008) Diabetes-related microvascular and macrovascular diseases in the physical therapy setting. Phys Ther 88: 1322-1335.

45. Li X, Zhang L, Meshinchi S, Dias-Leme C, Raffin D, et al. (2006) Islet microvasculature in islet hyperplasia and failure in a model of type 2 diabetes. Diabetes 55: 2965-2973.

46. Eberhard D, Kragl M, Lammert E (2010) 'Giving and taking': endothelial and beta-cells in the islets of Langerhans. Trends
Endocrinol Metab 21: 457-463.

47. Lehmann R, Zuellig RA, Kugelmeier P, Baenninger PB, Moritz W, et al. (2007) Superiority of small islets in human islet transplantation. Diabetes 56: 594-603.

48. Peiris H, Bonder CS, Coates PT, Keating DJ, Jessup CF (2014) The beta-cell/EC axis: how do islet cells talk to each other? Diabetes 63: 3-11.

49. Lin HM, Lee JH, Yadav H, Kamaraju AK, Liu E, et al. (2009) Transforming growth factor-beta/Smad3 signaling regulates insulin gene transcription and pancreatic islet beta-cell function. The Journal of biological chemistry 284: 1224612257.

50. Cao Z, Wang X (2014) The endocrine role between beta cells and intra-islet endothelial cells. Endocr J 61: 647-654.

51. Olerud J, Johansson M, Lawler J, Welsh N, Carlsson PO (2008) Improved vascular engraftment and graft function after inhibition of the angiostatic factor thrombospondin-1 in mouse pancreatic islets. Diabetes 57: 1870-1877.

52. Olerud J, Mokhtari D, Johansson M, Christoffersson G, Lawler J, et al. (2011) Thrombospondin-1: an islet endothelial cell signal of importance for beta-cell function. Diabetes 60: 1946-1954.

53. Johansson M, Mattsson G, Andersson A, Jansson L, Carlsson PO (2006) Islet endothelial cells and pancreatic beta-cell proliferation: studies in vitro and during pregnancy in adult rats. Endocrinology 147: 2315-2324.

54. Garcia-Ocana A, Takane KK, Syed MA, Philbrick WM, Vasavada RC, et al. (2000) Hepatocyte growth factor overexpression in the islet of transgenic mice increases beta cell proliferation, enhances islet mass, and induces mild hypoglycemia. The Journal of biological chemistry 275: 1226-1232.

55. Mellado-Gil J, Rosa TC, Demirci C, Gonzalez-Pertusa JA, Velazquez-Garcia S, et al. (2011) Disruption of hepatocyte growth factor/c-Met signaling enhances pancreatic beta-cell death and accelerates the onset of diabetes. Diabetes 60: 525536.

56. Parnaud G, Hammar E, Ribaux P, Donath MY, Berney T, et al. (2009) Signaling pathways implicated in the stimulation of beta-cell proliferation by extracellular matrix. Mol Endocrinol 23: 1264-1271.

57. Parnaud G, Hammar E, Rouiller DG, Armanet M, Halban PA, et al. (2006) Blockade of beta1 integrin-laminin-5 interaction affects spreading and insulin secretion of rat beta-cells attached on extracellular matrix. Diabetes 55: 1413-1420.

58. Nikolova G, Jabs N, Konstantinova I, Domogatskaya A, Tryggvason $\mathrm{K}$, et al. (2006) The vascular basement membrane: a niche for insulin gene expression and Beta cell proliferation. Dev Cell 10: 397-405.

59. Richards OC, Raines SM, Attie AD (2010) The role of blood vessels, endothelial cells, and vascular pericytes in insulin secretion and peripheral insulin action. Endocr Rev 31: 343363.

60. Charrier A, Chen R, Kemper S, Brigstock DR (2014) Regulation of pancreatic inflammation by connective tissue growth factor (CTGF/CCN2). Immunology 141: 564-576.

61. Corral Corral C (1989) [The patient and the health system. The function of the general physician based on the systems theory]. Med Clin (Barc) 92: 306-308.

62. Brissova M, Shostak A, Shiota M, Wiebe PO, Poffenberger G, et al. (2006) Pancreatic islet production of vascular endothelial 
growth factor--a is essential for islet vascularization, revascularization, and function. Diabetes 55: 2974-2985.

63. Dolensek J, Spelic D, Klemen MS, Zalik B, Gosak M, et al. (2015) Membrane Potential and Calcium Dynamics in Beta Cells from Mouse Pancreas Tissue Slices: Theory, Experimentation, and Analysis. Sensors (Basel) 15: 2739327419.

64. Ravier MA, Guldenagel M, Charollais A, Gjinovci A, Caille D, et al. (2005) Loss of connexin36 channels alters beta-cell coupling, islet synchronization of glucose-induced $\mathrm{Ca} 2+$ and insulin oscillations, and basal insulin release. Diabetes 54: 1798-1807.

65. Ali O (2013) Genetics of type 2 diabetes. World J Diabetes 4: 114-123.

66. Sobrevia L, Nadal A, Yudilevich DL, Mann GE (1996) Activation of L-arginine transport (system $y^{+}$) and nitric oxide synthase by elevated glucose and insulin in human endothelial cells. J Physiol 490(Pt 3): 775-781.

67. Delaney CA, Eizirik DL (1996) Intracellular targets for nitric oxide toxicity to pancreatic beta-cells. Braz J Med Biol Res 29: 569-579.

68. Barba-Gutierrez DA, Daneri-Navarro A, Villagomez-Mendez JJ, Kanamune J, Robles-Murillo AK, Sanchez-Enriquez S, et al. (2016) Facilitated Engraftment of Isolated Islets Coated With Expanded Vascular Endothelial Cells for Islet Transplantation. Transplant Proc 48: 669-672.

69. Zhang N, Richter A, Suriawinata J, Harbaran S, Altomonte J, et al. (2004) Elevated vascular endothelial growth factor production in islets improves islet graft vascularization. Diabetes 53: 963-970.

70. Khosravi-Maharlooei M, Hajizadeh-Saffar E, Tahamtani Y, Basiri M, Montazeri L, et al. (2015) THERAPY OF
ENDOCRINE DISEASE: Islet transplantation for type 1 diabetes: so close and yet so far away. Eur J Endocrinol 173: R165-183.

71. Park CG, Bottino R, Hawthorne WJ (2015) Current status of islet xenotransplantation. Int J Surg 23: 261-266.

72. Oleson BJ, McGraw JA, Broniowska KA, Annamalai M, Chen J, et sl. (2015) Distinct differences in the responses of the human pancreatic beta-cell line EndoC-betaH1 and human islets to proinflammatory cytokines. Am J Physiol Regul Integr Comp Physiol 309: R525-534.

73. Bellmann K, Jaattela M, Wissing D, Burkart V, Kolb H (1996) Heat shock protein hsp70 overexpression confers resistance against nitric oxide. FEBS Lett 391: 185-188.

74. Burkart V, Liu H, Bellmann K, Wissing D, Jaattela M, et al. (2000) Natural resistance of human beta cells toward nitric oxide is mediated by heat shock protein 70 . The Journal of biological chemistry 275: 19521-19528.

75. Eizirik DL, Mandrup-Poulsen T (2001) A choice of death--the signal-transduction of immune-mediated beta-cell apoptosis. Diabetologia 44: 2115-2133.

76. Martinez FO, Gordon S (2014) The M1 and M2 paradigm of macrophage activation: time for reassessment. F1000Prime Rep 6: 13.

77. Arnush M, Heitmeier MR, Scarim AL, Marino MH, Manning PT, et al. (1998) IL-1 produced and released endogenously within human islets inhibits beta cell function. J Clin Invest 102: 516-526.

78. Taborsky GJ, Jr (2011) Islets have a lot of nerve! Or do they? Cell Metab 14: 5-6.
Copyright: (C)2017 Eli C Lewis, et al. This is an open-access article distributed under the terms of the Creative Commons Attribution License, which permits unrestricted use, distribution, and reproduction in any medium, provided the original author and source are credited. 